\title{
FUZZIFICATION OF THE 'TOWS' STRATEGIC CONCEPT: A CASE STUDY OF THE MAGNETI MARELLI BRANCH IN THE SERBIAN AUTOMOTIVE INDUSTRY
}

\author{
D. Pesic $^{1 *}$, A. Pesic ${ }^{2}$, S. Ivkovic ${ }^{3}$ \& D. Apostolovic ${ }^{4}$ \\ ${ }^{1}$ Information Technology School, \\ Belgrade, Serbia \\ duska.pesic@its.edu.rs \\ ${ }^{2,3}$ Faculty for Business and Industrial Management, \\ Union University, Belgrade, Serbia \\ 2a.pesic@ups.rs, 3s.ivkovic@ups.rs \\ ${ }^{4}$ Magneti Marelli, Plastic Components and Modules Automotive SPA, \\ Kragujevac, Serbia \\ dejan.apostolovic@magna.com
}

\begin{abstract}
The purpose of this paper is to introduce a fuzzy approach to the quantification of the TOWS (Threats, Opportunities, Weaknesses, and Strengths) strategic concept (also known as 'SWOT'). Fuzzy logic and triangular fuzzy numbers are used to provide an alternate assessment of the internal strengths and weaknesses and external opportunities and threats in the process of developing strategic alternatives and making strategic choices. The developed fuzzy model is applied to a real-world case, conducted with the management team of the Magneti Marelli branch in Serbia, which operates as the largest supplier in the Serbian automotive industry. The results are discussed, and suggestions for further research are provided.
\end{abstract}

\section{OPSOMMING}

' $n$ Wasige benadering tot die kwantifisering van die TOWS (bedregings, geleenthede, swakpunte en sterkpunte) strategiese konsep word bekendgestel. Wasigheidsleer en driehoekige wasige nommers is gebruik om ' $n$ alternatiewe beoordeling van die interne sterk- en swakpunte en eksterne geleenthede en bedreigings in die strategiese alternatieweontwikkelingsproses en strategiesebesluitneming te verskaf. Die ontwikkelde wasige model is toegepas op ' $n$ gevallestudie van die bestuurspan van die Magneti Marelli tak in Serwië. Dit is die grootste verskaffer in die Serwiese voertuigindustrie. Die resultate is bespreek en voorstelle vir verdere navorsing is verskaf.

Corresponding author 
The TOWS matrix, developed by Weihrich [1], is generally used to facilitate information analysis in the process of systematising strategic choices. This management technique for matching environmental threats and opportunities with organisational weaknesses and strengths in order to formulate alternative strategies implies that internal strengths and weaknesses are summarised on the horizontal axis, while the external environmental opportunities and threats are summarised on the vertical axis [2].

In this concept, strengths include internal characteristics that the organisation can exploit to achieve strategic goals, while weaknesses denote internal difficulties and inhibitions that could restrict or prevent organisational goals from being attained. Conversely, threats are characteristics of the external environment that could negatively impact on achieving strategic goals, and opportunities are positive characteristics of the external environment that could help in accomplishing organisations goals and overall business success.

According to David [3], strategic alternatives are suggested by the interaction of the four sets of variables. For example, adaptive strategic alternatives could be developed by matching an organisation's relevant strengths with environmental opportunities, relevant strengths with environmental threats, weaknesses with environmental opportunities, and weaknesses with environmental threats.

Although the TOWS matrix can be used identify relationships, it can become a complex process when many factors are involved. Weihrich [4] suggested that combinations of relationships could be presented by introducing a plus: ' + ' (a match between the strengths of the organisation and external environmental opportunities). In that case very strong relationships are indicated by two plusses: '++'. In other situations, a weak or nonexistent relationship is indicated by a zero: ' 0 '.

The problem is that different relationships do not have the same weight in terms of their potential. So a prioritisation of the factors, and lack of considering two-sided factors, must also be taken into the consideration. For instance, there are many situations when external factors cannot be fully recognised as either opportunities or threats because their impact on the organisation could be viewed across a wide range that includes both positive and negative effects [5].

In this paper, fuzzy logic has been used to represent mathematically the vague aspects of internal organisational and external environmental factors and to provide useful assistance in the strategy formulation process.

Zimmermann [6] stressed that, since Zadeh introduced fuzzy set theory in 1965, the use of fuzzy logic has arisen in management and organisational decision models, primarily because it provides a strict mathematical framework within which vague phenomena can be precisely and rigorously studied. That is, the intention of fuzzy set theory is to provide a natural way of dealing with problems in which the source of imprecision is the absence of sharply-defined criteria of class memberships [7]. Jia and Bai [8] also integrated fuzzy set theory to deal with vagueness in decision process inputs, while Wang and Elhang [9] pointed out that the normalisation of interval and fuzzy weights is often necessary in decisionmaking. Summing up, Chinho and Hsieh [10] argued that fuzzy set theory could be seen as a mathematical sub-discipline, and as a tool for decision-making under ambiguous conditions.

Generally, recent investigations show the benefits of applying fuzzy set theory when dealing with diverse types of uncertainty [11].

We used a fuzzy set theory framework for developing a fuzzy TOWS model. The model is explained in the second section of this paper. The first step in the model implies that internal and external factors are converted into membership functions. Then the linguistic 
variables in the series of IF-THEN rules are introduced into the model (simple rules cover every combination of the fuzzy values); and as the last step, through the process of defuzzification, fuzzy output is converted into ordinary crisp numbers.

In Section 3, an empirical application illustrates the possible use of the fuzzy TOWS model. The model is applied to a case study of the Magneti Marelli production unit in Serbia. The research was conducted with senior and line managers in the Serbian branch of this Italian company, which is a worldwide leader in components and automotive parts manufacturing, as well as the most important supplier in the Serbian automotive industry.

The fuzzy TOWS model is used to help managers in the company to define their strategic priorities and to develop optimal strategies by introducing an $\alpha$-level fuzzy set. In the final section of the paper the results and implications are discussed.

\section{FUZZY MODELLING OF THE TOWS CONCEPT}

The fuzzy TOWS model proposed in this paper is divided into seven phases. The whole process of fuzzification and defuzzification is shown in Figure 1.

1. Identification of the Internal and External Factors
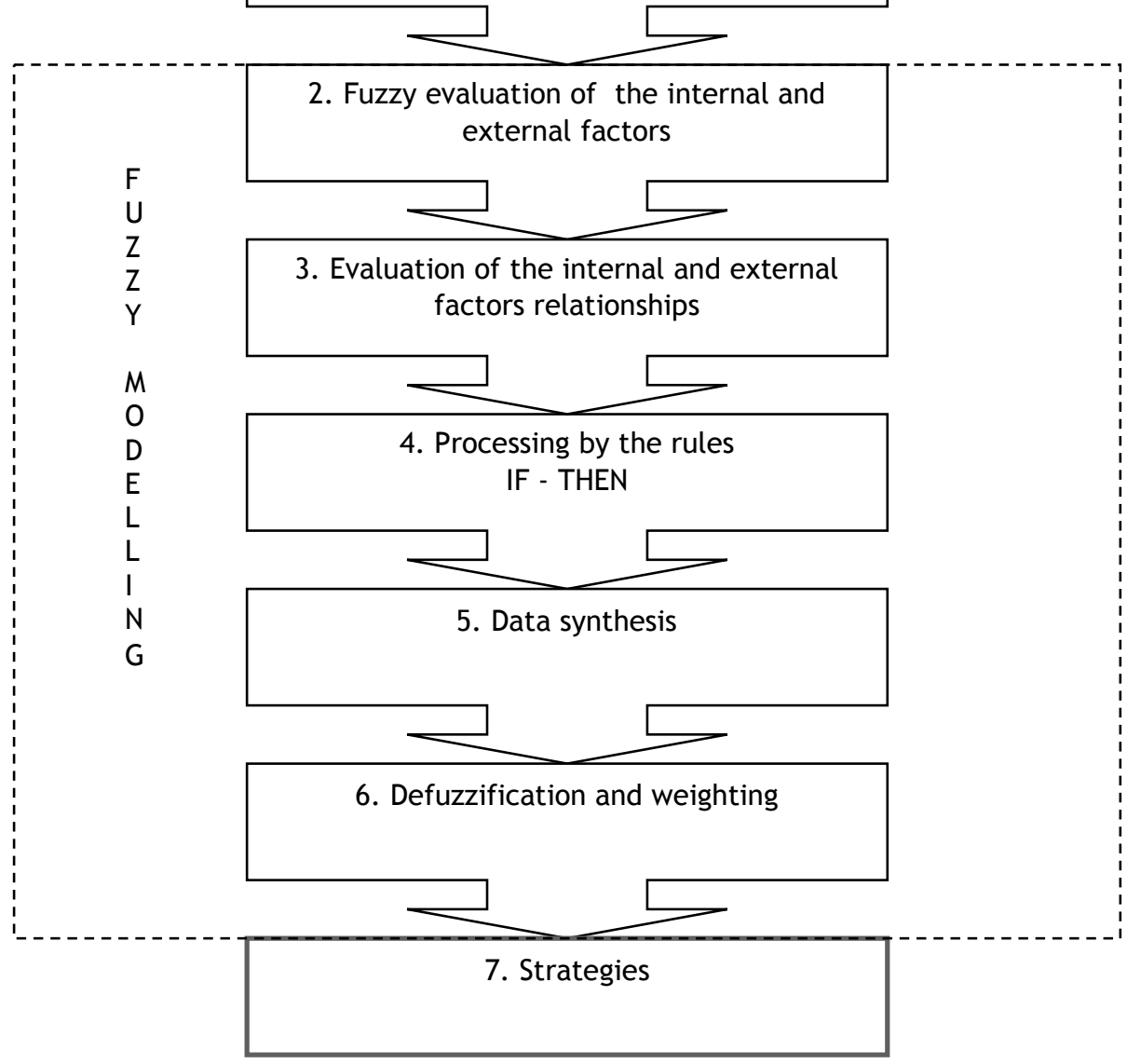

Figure 1: The fuzzy TOWS model 


\section{Phase 1}

This phase involves identification of the relevant internal and external factors. Internal factors are labelled as $I_{j}, j=1, \ldots, m$ and external factors are labelled as $E_{i}, i=1, \ldots, n$.

\section{Phase 2}

Two input linguistic variables are introduced:

- The state of internal organisational factors

- The state of external environmental factors

Both input variables include four linguistic terms. Triangular and trapezoidal fuzzy sets whose membership functions have a graph composed of parts of the triangular and trapezoidal shape are used to deal with the vagueness of human judgments [12].

The states of the internal factors are described by the following linguistic terms:

- $\quad M W$ - Major weakness

- $\quad \mathrm{mW}$ - Minor weakness

- $\quad \mathrm{mS}$ - Minor strength

- MS - Major strength

The membership functions of the internal factors have a graph, presented in Figure 2.

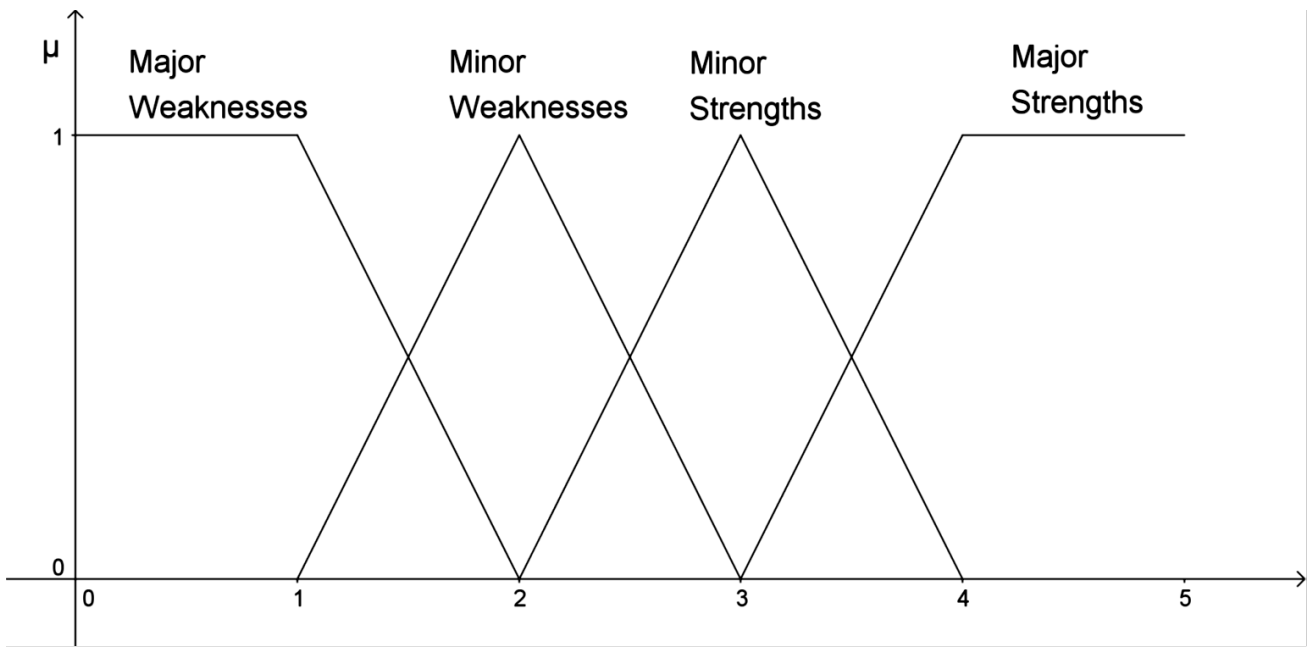

Figure 2: Linguistic variable - internal factors

The states of the external factors $E_{i}, i=1, \ldots, n$ are described by the following linguistic terms:

- $\quad$ MT - Major threat

- $\quad \mathrm{mT}$ - Minor threat

- mO - Minor opportunity

- $\quad$ MO - Major opportunity

The membership functions of the external factors have a graph, presented in Figure 3. 


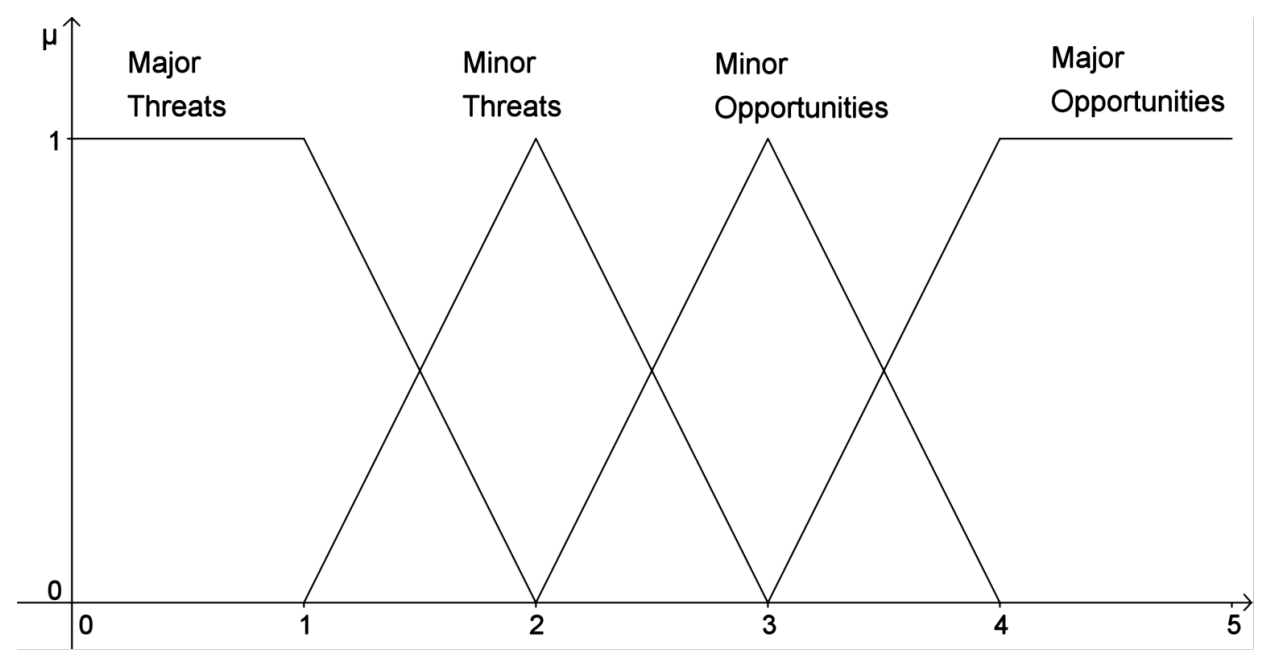

Figure 3: Linguistic variable - external factors

Assessment of the internal and external factors includes interval[0,5]. If the estimated value of the factor is closer to the number 5 , that factor represents a major strength. On the other hand, if the estimated value of the factor is closer to the number 0 , that factor represents a major weakness. By analogy, it applies to the external factors (opportunities and threats) too.

Phase 3

Phase 3 refers to the complexity of the interactions of internal and external factors. Weihrich [1] suggested the formation of the Interaction matrix, where the sign ' +' indicates a match between the strengths of the organisation and external opportunities, while ' 0 ' indicates a weak or non-existent relationship. If an especially strong relationship exists, it can be indicated by two plusses ('++'). The fuzzy TOWS model, as an alternative approach, implies that the Interaction matrix contains numbers from $[0,1]$ interval, where the number represents the degree of the correlation of the factors and also indicates the weight that affects the value of the organisational strategies.

\section{Phase 4}

In phase 4 . the input variables are processed by the 'IF - THEN' rules. Sixteen rules are considered, which are obtained by combining the four linguistic terms for the internal factors with those for the external factors (Table 1). The use of fuzzy rules allows managers to work effectively with linguistic semantics [13].

Table 1: Development of strategic alternatives

\begin{tabular}{|c|c|c|c|c|c|}
\hline & \multicolumn{5}{|c|}{ Internal factors } \\
\hline \multirow{5}{*}{$\begin{array}{l}\text { External } \\
\text { factors }\end{array}$} & & MW & $\mathrm{mW}$ & $\mathrm{mS}$ & MS \\
\hline & MT & $\begin{array}{c}\text { min-min } \\
(\mathrm{mm})\end{array}$ & $\begin{array}{c}\text { min-min } \\
(\mathrm{mm})\end{array}$ & $\begin{array}{c}\text { Max-min } \\
(\mathrm{Mm})\end{array}$ & $\begin{array}{c}\text { Max-min } \\
(\mathrm{Mm})\end{array}$ \\
\hline & $\mathrm{mT}$ & $\begin{array}{c}\min -\min \\
(\mathrm{mm})\end{array}$ & $\begin{array}{c}\min -\min \\
(\mathrm{mm})\end{array}$ & $\begin{array}{c}\text { Max-min } \\
(\mathrm{Mm})\end{array}$ & $\begin{array}{c}\text { Max-min } \\
(\mathrm{Mm})\end{array}$ \\
\hline & $\mathrm{mo}$ & $\begin{array}{c}\min -M a x \\
(\mathrm{mM})\end{array}$ & $\begin{array}{c}\min -M a x \\
(\mathrm{mM})\end{array}$ & $\begin{array}{c}\text { Max-Max } \\
\text { (MM) }\end{array}$ & $\begin{array}{c}\text { Max-Max } \\
(\mathrm{MM})\end{array}$ \\
\hline & MO & $\begin{array}{c}\min -M a x \\
(\mathrm{mM})\end{array}$ & $\begin{array}{c}\min -M a x \\
(\mathrm{mM})\end{array}$ & $\begin{array}{c}\text { Max-Max } \\
\text { (MM) }\end{array}$ & $\begin{array}{c}\text { Max-Max } \\
(\mathrm{MM})\end{array}$ \\
\hline
\end{tabular}


The process of developing strategic alternatives is based on the approach suggested by Weihrich [4], who pointed out that - on the basis of the analysis of the external and internal environments - four distinct strategies could be available:

1. Maxi-maxi strategy $(M M)$, or SO strategy, (which aims to maximise both internal strengths and external opportunities).

2. Maxi-mini strategy $(\mathrm{Mm})$, or ST strategy, (which maximises the internal strengths while minimising the external threats).

3. Mini-maxi strategy $(\mathrm{mM})$ ), or WO strategy, (which minimises the internal weaknesses and takes advantage of external opportunities).

4. Mini-mini strategy $(\mathrm{mm})$, or WT strategy. (which aims to minimise both the internal weaknesses and the external threats).

The rules 'IF - THEN' that lead to the optimal strategy are explained below. (The output variables depend on the values of the input variables that go through all the 'rules'; usually there are more iterations.)

1. IF internal factor represents major weakness $(I=M W)$ and external factor represents major threat ( $E=M T$ ) THEN strategy is min-min $(S=m m)$

2. IF internal factor represents major weakness $(I=M W)$ and external factor represents minor threat ( $E=m T)$ THEN strategy is min-min $(S=m m)$

3. IF internal factor represents major weakness $(I=M W)$ and external factor represents minor opportunity $(E=m O)$ THEN strategy is $\min -\operatorname{Max}(S=m M)$

4. IF internal factor represents major weakness $(I=M W)$ and external factor represents major opportunity ( $E=M O)$ THEN strategy is $\min -\operatorname{Max}(S=m M)$

5. IF internal factor represents minor weakness $(I=m W)$ and external factor represents major threat ( $E=M T$ ) THEN strategy is min-min $(S=m m)$

6. IF internal factor represents minor weakness $(I=m W)$ and external factor represents minor threat ( $E=m T$ ) THEN strategy is min-min $(S=m m$ )

7. IF internal factor represents minor weakness $(I=m W)$ and external factor represents minor opportunity $(E=m O)$ THEN strategy is min-Max $(S=m M)$

8. IF internal factor represents minor weakness $(I=m W)$ and external factor represents major opportunity ( $E=M O)$ THEN strategy is $\min -\operatorname{Max}(S=m M)$

9. IF internal factor represents minor strength $(I=m S)$ and external factor represents major threat ( $E=M T$ ) THEN strategy is Max-min $(S=M m$ )

10. IF internal factor represents minor strength $(I=m S)$ and external factor represents minor threat $(E=m T)$ THEN strategy is Max-min $(S=M m)$

11. IF internal factor represents minor strength $(I=m S)$ and external factor represents minor opportunity $(E=m O)$ THEN strategy is $\operatorname{Max}-\operatorname{Max}(S=M M)$

12. IF internal factor represents minor strength $(I=m S)$ and external factor represents major opportunity $(E=M O)$ THEN strategy is Max-Max $(S=M M)$

13. IF internal factor represents major strength $(I=M S)$ and external factor represents major threat $(E=M T)$ THEN strategy is Max-min $(S=M m)$

14. IF internal factor represents major strength ( $I=M S)$ and external factor represents minor threat $(E=m T)$ THEN strategy is $\operatorname{Max}-\min (S=M m)$

15. IF internal factor represents major strength $(I=M S)$ and external factor represents minor opportunity ( $E=m O$ ) THEN strategy is Max-Max ( $S=M M$ )

16. IF internal factor represents major strength $(I=M S)$ and external factor represents major opportunity ( $E=M O)$ THEN strategy is $\operatorname{Max}-\operatorname{Max}(S=M M)$ 
Phase 5

In Phase 5, each value of the output variable is associated with the corresponding degree of membership of the fuzzy set 'Strategy', whose graph is shown in Figure 4.

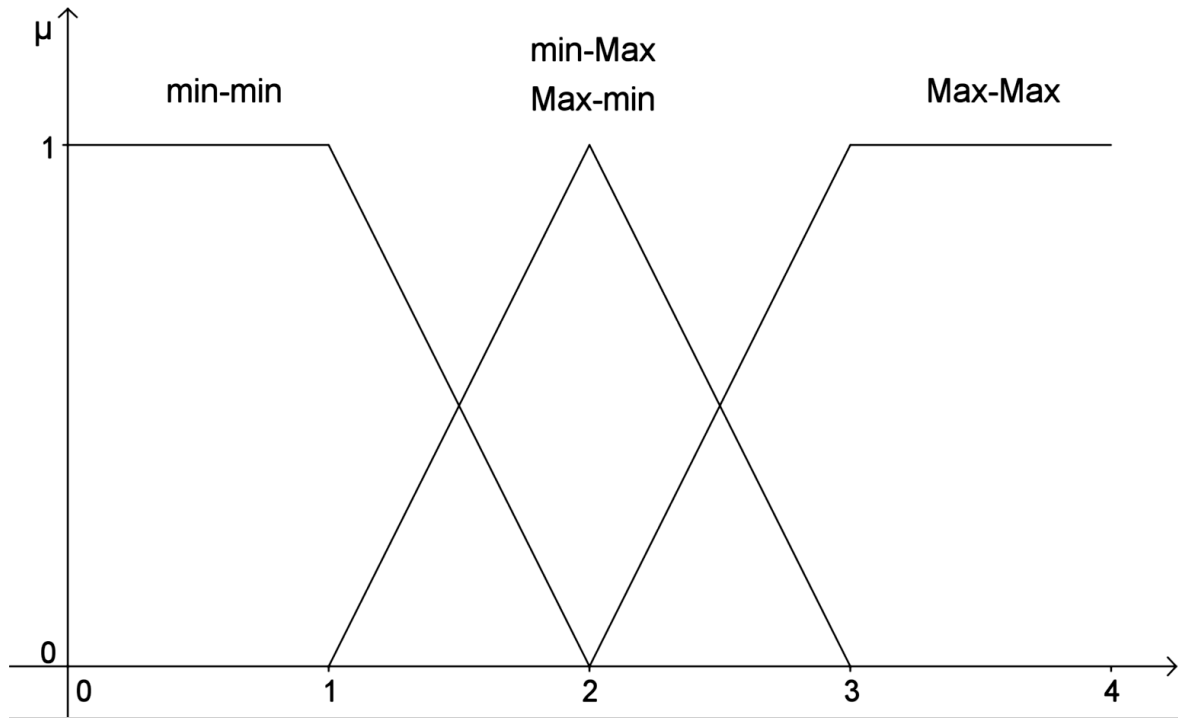

Figure 4: Linguistic variable - Strategy

Phase 6

In the sixth phase the results are multiplied by the weight. This calculation changes the final value of the strategy, depending on the strength of the corresponding pair (internalexternal factor) correlation. For example, if the correlation of two factors is estimated to be 0.4 , then we take 40 per cent of the value obtained. Finally, the results are defuzzified using one of the methods of defuzzification in order to get the result represented as an ordinary crisp number. Generally, selection of a defuzzification procedure depends on the properties of the application [14].

\section{Phase 7}

The results obtained are inserted into the matrix. In that way, the fuzzy TOWS matrix includes strategies and the degree to which a particular strategy is the optimal strategy in the actual situation. In order to decide which of the strategies should be retained as optimal solutions, an $\alpha$-level of the fuzzy set is used. By introducing an $\alpha$-level of the fuzzy set into the fuzzy TOWS matrix, the best strategies are easily marked off and segregated.

\section{CASE STUDY: MAGNETI MARELLI PRODUCTION FACILITY IN SERBIA}

The Serbian branch of the Italian company Magneti Marelli has been chosen for the case study for two reasons. First, the automotive industry in Serbia plays an important role in the manufacturing sector of the domestic economy. Second, Magneti Marelli is well-known as a worldwide supplier for the automotive sector, and has 85 production facilities, 12 R\&D centres, and 26 application centres in Europe, Asia, North America, and Latin America.

For this study, it is important to explain that the origins of the Serbian automotive industry date back to 1939; but the first large-scale production of automobiles took place after the Second World War. At that time, under licence to the Italian manufacturer Fiat, the existing factory in Kragujevac was renamed 'Zastava Automobiles'.

Over the next few decades Zastava achieved an annual production of nearly 300,000 units, but, owing to political problems and economic sanctions during the 1990s, the production 
of motor vehicles decreased dramatically at the beginning of the 21 st century. As a result of the long-term financial crisis, the Fiat Group took over the Zastava plant in 2008.

Following this, in order to establish Serbia as a new manufacturing location for the automotive industry in Europe, the Serbian government and Magneti Marelli (a subsidiary of the Fiat Group) signed an agreement to open a new industrial site in the Kragujevac area.

Since 2010, the Magneti Marelli production facility in Serbia has supplied the local market with components, mainly for the operations of Fiat Auto Serbia (FAS).

\subsection{The implementation of the fuzzy TOWS model}

In practice, many decisions are based on the opinions of experts and on their qualitative statements [15]. Thus many organisational decisions and situation assessments that involve various uncertain factors are often carried out by groups of experts [16]. In our case study of Magneti Marelli, the appraisal of organisational internal factors and environmental external factors has been conducted with a group of managers from different management levels in the company.

Within the suggested framework, the first step was the analysis of the market and competitive situation, the technology, and important economic, political, social, and demographic factors. Apart from the external environment analysis, it was also necessary to identify significant internal factors that might be found in the management, finance, marketing, and in other functional areas of the organisation.

The situation analysis by the managers of Magneti Marelli identified six relevant external factors and seven relevant internal factors that had immediate significance for the company's business in Serbia.

The selected external factors are designated in the following way: Competition from Johnson Controls - $E_{1}$; New models coming to Serbia (e.g., Jeep) - $E_{2}$; Development of the market in the region - $E_{3}$; Support from the Serbian government - $E_{4}$; Slackening demand for the Fiat 500L, which is made in Serbia - $E_{5}$; Lack of local experts and inappropriate infrastructure $-E_{6}$.

The internal factors are denoted as follows: Assured certain demand by Fiat - $I_{1}$; High costs of equipment and fixed production costs $-I_{2}$; Strong R\&D $-I_{3}$; Relying on one primary customer (Fiat) - $I_{4 ;}$ Tacit knowledge and codified knowledge about products and processes - $I_{5}$; One plant location (close to Fiat) - $I_{6}$; Long-term global presence and identifiable corporate name $-I_{7}$.

The next issue investigated was the evaluation of the value of selected factors. Since the proposed model of assessment implies numbers from the $[0,5]$ interval, the following results were obtained:

Table 2: The value of internal factors

\begin{tabular}{|l|c|c|c|c|c|c|c|}
\hline Internal factor & $I_{1}$ & $I_{2}$ & $I_{3}$ & $I_{4}$ & $I_{5}$ & $I_{6}$ & $I_{7}$ \\
\hline Assigned value & 2.6 & 1.7 & 4.7 & 2.1 & 3.1 & 2.5 & 3.9 \\
\hline
\end{tabular}

Table 3: The value of external factors

\begin{tabular}{|l|c|c|c|c|c|c|}
\hline External factor & $E_{1}$ & $E_{2}$ & $E_{3}$ & $E_{4}$ & $E_{5}$ & $E_{6}$ \\
\hline Assigned value & 1.7 & 3.9 & 4.6 & 4.1 & 1.2 & 0.9 \\
\hline
\end{tabular}

The linguistic variables described earlier in this paper were used to obtain the degree to which the internal and external factors belonged to the given fuzzy sets. The data can be seen in Tables 4 and 5. 
Table 4: The degree of belonging to fuzzy sets (internal factors)

\begin{tabular}{|c|c|c|c|c|c|c|c|c|}
\hline Fuzzification & Internal factor & $I_{1}$ & $I_{2}$ & $I_{3}$ & $I_{4}$ & $I_{5}$ & $I_{6}$ & $I_{7}$ \\
\hline The degree of & $M W$ & 0 & 0.3 & 0 & 0 & 0 & 0 & 0 \\
belonging to fuzzy & $m W$ & 0.4 & 0.7 & 0 & 0.9 & 0 & 0.5 & 0 \\
sets & $m S$ & 0.6 & 0 & 0 & 0.1 & 0.9 & 0.5 & 0.1 \\
& $M S$ & 0 & 0 & 1 & 0 & 0.1 & 0 & 0.9 \\
\hline
\end{tabular}

Table 5: The degree of belonging to fuzzy sets (external factors)

\begin{tabular}{|c|c|c|c|c|c|c|c|}
\hline Fuzzification & External factor & $E_{1}$ & $E_{2}$ & $E_{3}$ & $E_{4}$ & $E_{5}$ & $E_{6}$ \\
\hline \multirow{2}{*}{$\begin{array}{c}\text { The degree of } \\
\text { belonging to fuzzy }\end{array}$} & $M T$ & 0.3 & 0 & 0 & 0 & 0.8 & 1 \\
sets & $m T$ & 0.7 & 0 & 0 & 0 & 0.2 & 0 \\
& $m O$ & 0 & 0.1 & 0 & 0 & 0 & 0 \\
& $M O$ & 0 & 0.9 & 1 & 1 & 0 & 0 \\
\hline
\end{tabular}

In Figure 5, examples of the graphs of internal factor $I_{2}$ and external factor $E_{3}$ are shown.

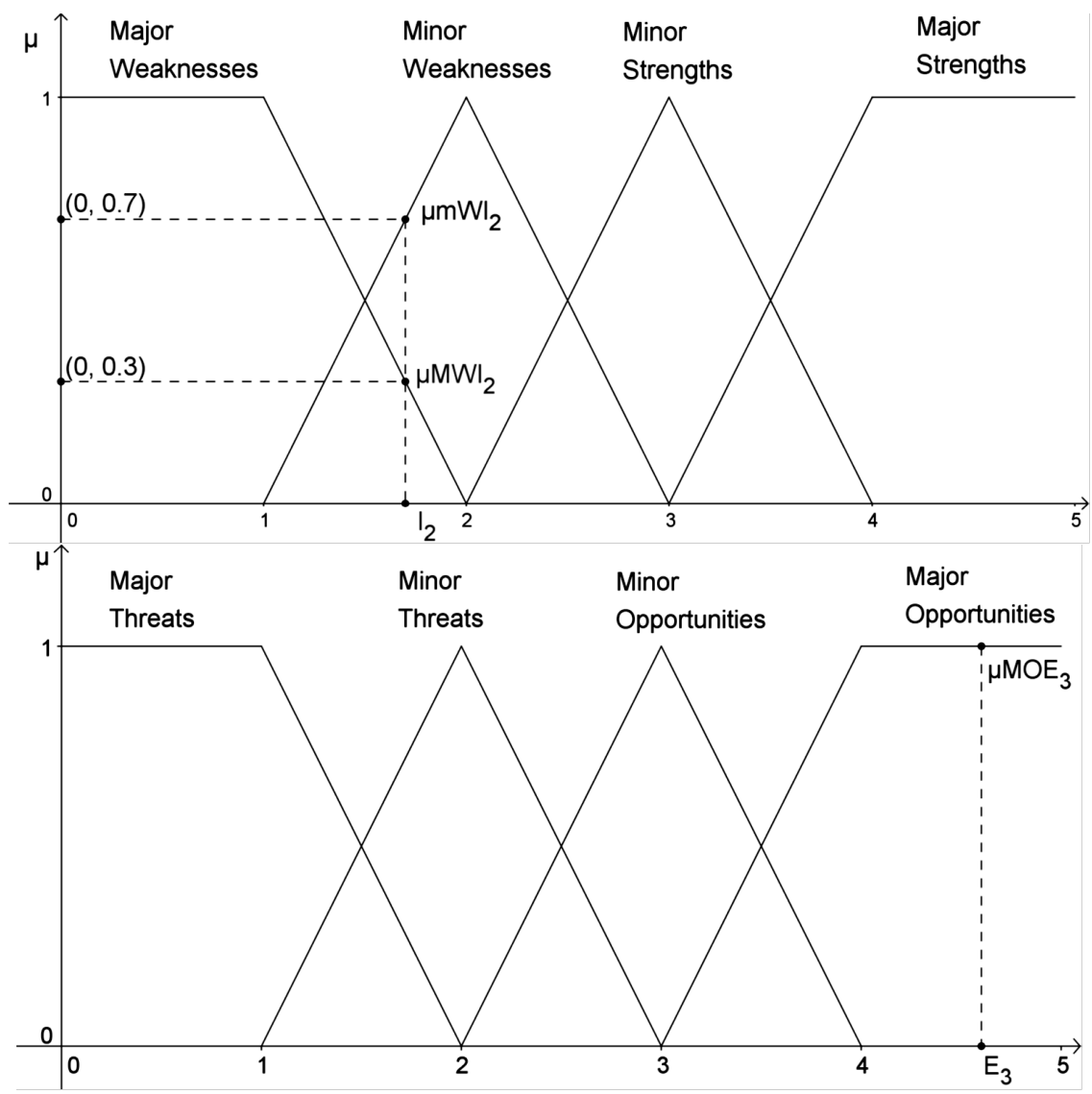

Figure 5: Graphs of internal factor $I_{2}$ and external factor $E_{3}$

Based on the assessment method proposed by Weihrich [1], a team of operational managers from Magneti Marelli assessed the strength of correlation between the internal and external 
factors, using numbers from the $[0,1]$ interval. Those numbers represent the degree of correlation of the factors, and also indicates the weight that affects the value of the organisational strategies. The data obtained is shown in the interactions matrix (Table 6).

Table 6: Interactions matrix

\begin{tabular}{|c|c|c|c|c|c|c|c|}
\hline External/Internal & $I_{1}$ & $I_{2}$ & $I_{3}$ & $I_{4}$ & $I_{5}$ & $I_{6}$ & $I_{7}$ \\
\hline$E_{1}$ & 0.2 & 1 & 0.7 & 0.3 & 0.5 & 0 & 0.6 \\
$E_{2}$ & 0.4 & 0.2 & 0.3 & 0.5 & 1 & 0.7 & 1 \\
$E_{3}$ & 1 & 0.1 & 0.8 & 0.3 & 0.7 & 0.4 & 0 \\
$E_{4}$ & 0.9 & 0.5 & 0.9 & 0.1 & 0 & 1 & 0.3 \\
$E_{5}$ & 0.8 & 1 & 0 & 0.8 & 0.9 & 0.2 & 0.3 \\
$E_{6}$ & 0 & 0.6 & 1 & 0.2 & 0.8 & 0.5 & 0.6 \\
\hline
\end{tabular}

In order to develop the optimal strategies, the next step was to process the data with the IF-THEN rules, intersecting each internal factor with each external factor.

The following example refers to a combination of the factors $I_{1}$ and $E_{1}$. Using only part of the table and the corresponding decision rules, we obtained:

\begin{tabular}{|c||cc|}
\hline & $\mu_{m W}\left(I_{1}\right)=0.4$ & $\mu_{m S}\left(I_{1}\right)=0.6$ \\
\hline \hline$\mu_{M T}\left(E_{1}\right)=0.3$ & $\mu_{m m}\left(S_{11}\right)$ & $\mu_{M m}\left(S_{11}\right)$ \\
$\mu_{m T}\left(E_{1}\right)=0.7$ & $\mu_{m m}\left(S_{11}\right)$ & $\mu_{M m}\left(S_{11}\right)$ \\
\hline
\end{tabular}

The rules applied were 5, 6, 9, and 10, and the strength of these rules was determined as follows:

$$
\begin{aligned}
& \alpha_{1}=\mu_{m W}(2.6) \wedge \mu_{M T}(1.7)=\min (0.4,0.3)=0.3 \\
& \alpha_{2}=\mu_{m W}(2.6) \wedge \mu_{m T}(1.7)=\min (0.4,0.7)=0.4 \\
& \alpha_{3}=\mu_{m S}(2.6) \wedge \mu_{M T}(1.7)=\min (0.6,0.3)=0.3 \\
& \alpha_{4}=\mu_{m S}(2.6) \wedge \mu_{m T}(1.7)=\min (0.6,0.7)=0.6
\end{aligned}
$$

Controlled output using the rules was:

$$
\begin{aligned}
& \text { Rule 5: } \alpha_{1} \wedge \mu_{m m}\left(S_{11}\right)=\min \left(0.3, \mu_{m m}\left(S_{11}\right)\right) \\
& \text { Rule 6: } \alpha_{2} \wedge \mu_{m m}\left(S_{11}\right)=\min \left(0.4, \mu_{m m}\left(S_{11}\right)\right) \\
& \text { Rule 9: } \alpha_{3} \wedge \mu_{M m}\left(S_{11}\right)=\min \left(0.3, \mu_{M m}\left(S_{11}\right)\right) \\
& \text { Rule10: } \alpha_{4} \wedge \mu_{M m}\left(S_{11}\right)=\min \left(0.6, \mu_{M m}\left(S_{11}\right)\right)
\end{aligned}
$$

The rule 5 is included in the rule 6 , and the rule 9 is included in the rule 10 . Thus the output can be shown as:

$$
\mu_{S}\left(S_{11}\right)=\max \left\{\min \left(0.4, \mu_{m m}\left(S_{11}\right)\right), \min \left(0.6, \mu_{M m}\left(S_{11}\right)\right)\right\}
$$




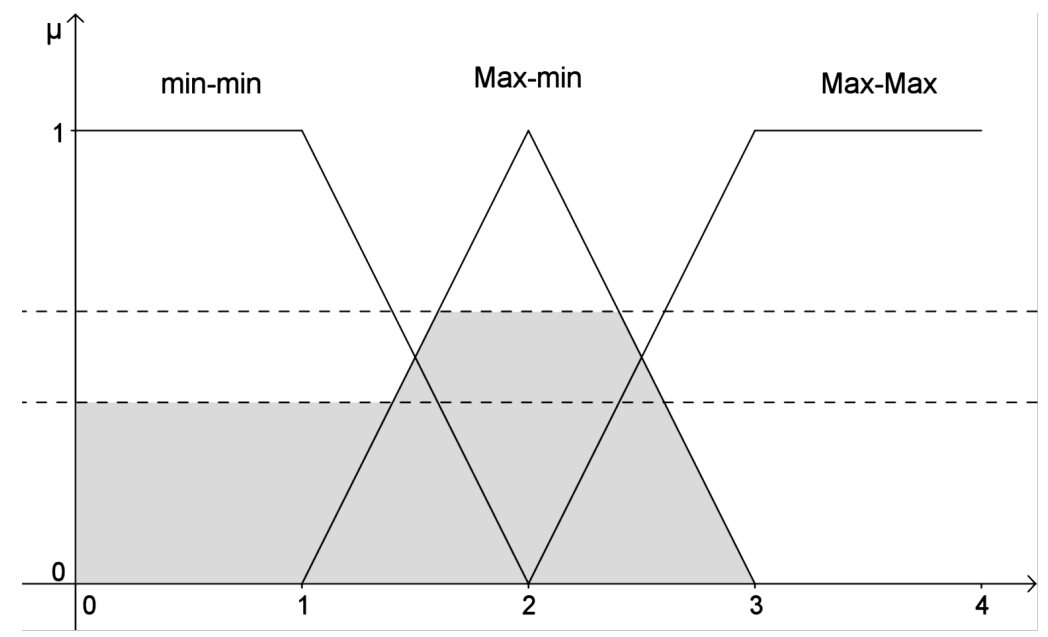

Figure 6: Unified field of the output - Strategy $S_{11}$

When we multiplied the obtained values of the strategies by the corresponding weight $\mu_{i, j}$ from the interactions matrix, the following results were obtained:

$$
\begin{aligned}
& \lambda_{11} \mu_{m m}\left(S_{11}\right)=0.2 \times 0.4=0.08 \\
& \lambda_{11} \mu_{M m}\left(S_{11}\right)=0.2 \times 0.6=0.12
\end{aligned},
$$

This process minimises the impact of these strategies (Figure 7).

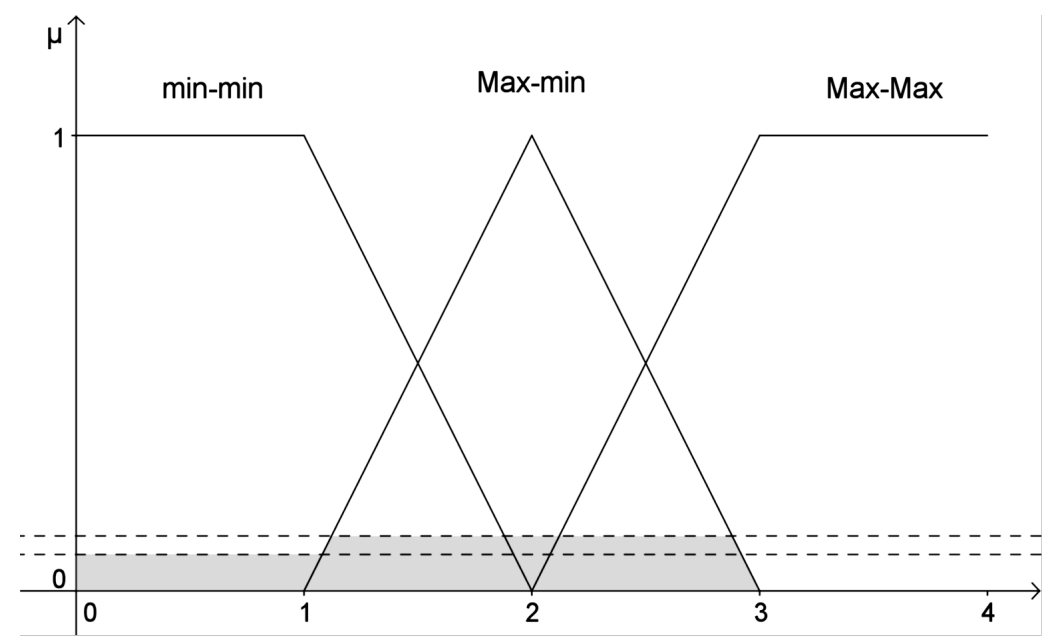

Figure 7: Weighted unified field of the output - Strategy $S_{11}$

Although there are various methods of defuzzification [5], we used the 'central of area method' (CAM). In this case CAM was expressed as:

$$
\bar{S}=\frac{0.5 \times 0.08+1 \times 0.08+1.5 \times 0.12+2 \times 0.12+2.5 \times 0.12}{0.08+0.08+0.12+0.12+0.12}=1.6154 \text {, }
$$

and the strategy was Max-min with degree $\mu_{M m}\left(S_{11}\right)=0.12$. 


\subsection{Results and discussion}

Upon completion of the process described, with all combinations of the internal and external factors, the fuzzy matrix can be shown as shown in Table 7. After defuzzification, the results given in Table 8 were obtained.

Table 7: Fuzzy matrix

\begin{tabular}{|c|c|c|c|c|c|c|c|}
\hline Internal & \multirow[t]{2}{*}{$I_{1}$} & \multirow[t]{2}{*}{$I_{2}$} & \multirow[t]{2}{*}{$I_{3}$} & \multirow[t]{2}{*}{$I_{4}$} & \multirow[t]{2}{*}{$I_{5}$} & \multirow[t]{2}{*}{$I_{6}$} & \multirow[t]{2}{*}{$I_{7}$} \\
\hline External & & & & & & & \\
\hline$E_{1}$ & $\begin{array}{l}\mathrm{mm} 0.08 \\
\mathrm{Mm0} 0.12\end{array}$ & $\mathrm{~mm} 0.7$ & $\mathrm{Mm0.49}$ & $\begin{array}{l}\mathrm{mm} 0.21 \\
\mathrm{Mm} 0.03\end{array}$ & $\mathrm{Mm0.35}$ & - & $\mathrm{Mm} 0.42$ \\
\hline$E_{2}$ & $\begin{array}{l}\mathrm{mM0} 0.16 \\
\text { MM0.24 }\end{array}$ & $\mathrm{mM0} 0.14$ & MMO.27 & $\begin{array}{l}\mathrm{mM0.45} \\
\text { MM0.05 }\end{array}$ & MM0.9 & $\begin{array}{l}\mathrm{mMO} 0.35 \\
\text { MM0.35 }\end{array}$ & MM0.9 \\
\hline$E_{3}$ & $\begin{array}{l}\mathrm{mM0.4} \\
\mathrm{MM0.6} \\
\end{array}$ & $\mathrm{mM0.07}$ & MM0.8 & $\begin{array}{l}\mathrm{mM} 0.27 \\
M M 0.03 \\
\end{array}$ & MM0.63 & $\begin{array}{l}\mathrm{mM0} 0.2 \\
\mathrm{MM0.2}\end{array}$ & - \\
\hline$E_{4}$ & $\begin{array}{l}\mathrm{mM0} 0.36 \\
\mathrm{MM0} 0.54\end{array}$ & $\mathrm{mM0} 0.35$ & MM0.9 & $\begin{array}{l}\mathrm{mM0} 0.09 \\
\mathrm{MM0.01}\end{array}$ & - & $\begin{array}{l}\mathrm{mM0} .5 \\
\mathrm{MMO} 0.5 \\
\end{array}$ & MM0.27 \\
\hline$E_{5}$ & $\begin{array}{l}\mathrm{mm} 0.32 \\
\mathrm{Mm0} 0.48\end{array}$ & $\mathrm{mm0.7}$ & - & $\begin{array}{l}\mathrm{mm0} 0.64 \\
\mathrm{Mm0} 0.08\end{array}$ & $M m 0.72$ & $\begin{array}{l}\mathrm{mm} 0.1 \\
\mathrm{Mm} 0.1\end{array}$ & $\mathrm{Mm} 0.24$ \\
\hline$E_{6}$ & - & $\mathrm{mm} 0.42$ & Mm1 & $\begin{array}{l}\mathrm{mm0} 0.18 \\
\mathrm{Mm} 0.02\end{array}$ & $\mathrm{Mm} 0.72$ & $\begin{array}{l}\mathrm{mm} 0.25 \\
\mathrm{Mm} 0.25\end{array}$ & $\mathrm{Mm} 0.54$ \\
\hline
\end{tabular}

In order to select the best strategies, the $\alpha$-level fuzzy set $\bar{S}_{\alpha}$ was used. Based on the decision of the management team, strategies with a degree of membership equal or higher than $\alpha=0.7$ were extracted. Consequently, the following strategies became available to the Magneti Marelli management team: $\bar{S}_{0.7}=\left\{S_{12}, S_{25}, S_{27}, S_{33}, S_{43}, S_{52}, S_{55}, S_{65}\right\}$.

The optimal strategies are defined as follows: $S_{12}$ - Diversify products due to competition and reduce production costs using experience curve; $S_{25}$ - Invest in production facilities to meet demand for new products; $S_{27}$ - Exploit good reputation and production location close to Fiat to make new business arrangements; $S_{33}$ - Take advantage of tacit knowledge and codified knowledge about products and processes to expand production of components for similar industries in the region; $S_{43}$ - Use Serbian government, which is willing to motivate foreign investors and extensive R\&D capabilities to increase presence in Serbia; $S_{52}$ - Reduce costs through flexible manufacturing; $S_{55}$ - Reinforce marketing activities and expand production of other plastic parts in the automotive industry; $S_{65}$ - Intensify investments in technology transfer from Italy.

Considering the very good reputation and image of Magneti Marelli in the supplier industry on the one hand, and the supportive policy of the Serbian government towards foreign investors on the other, it is not surprising that four of the eight selected strategies are Maxi-maxi strategies $\left(S_{25}, S_{27}, S_{33}\right.$ and $\left.S_{43}\right)$. Thus Magneti Marelli is in a position to build on its internal strengths, such as technical know-how, strong R\&D, manufacturing facilities, and identifiable corporate name, to take advantage of the opportunities in Serbia and in the region. Accordingly, Magneti Marelli's capabilities can be used to diversify its products and to meet new external demand.

Since Fiat Automotive Serbia, as a primary customer, ensures stable production for the Magneti Marelli facilities in Serbia, any possible negative trend - such as a declining demand for the Fiat automobiles produced in Serbia (the Fiat 500L) - represents an external threat to Magneti Marelli. An even greater threat to Magneti Marelli's operations in Serbia is the lack of local experts and inappropriate infrastructure. To cope with such threats, Magneti Marelli can make use of its strengths. For that purpose, two specific Mini-maxi strategies $\left(S_{55}\right.$ and $\left.S_{65}\right)$ can be used. 
Table 8: TOWS - strategies and the degree to which a particular strategy represents the optimal strategy in the actual situation

\begin{tabular}{|c|c|c|c|c|c|c|c|}
\hline & $I_{1}$ & $I_{2}$ & $I_{3}$ & $I_{4}$ & $I_{5}$ & $I_{6}$ & $I_{7}$ \\
\hline$E_{1}$ & $\begin{array}{l}\mu_{M m}\left(S_{11}\right) \\
=0.12\end{array}$ & $\begin{array}{l}\mu_{m m}\left(S_{12}\right) \\
=0.7\end{array}$ & $\begin{array}{l}\mu_{M m}\left(S_{13}\right) \\
=0.49\end{array}$ & $\begin{array}{l}\mu_{m m}\left(S_{14}\right) \\
=0.21\end{array}$ & $\begin{array}{l}\mu_{M m}\left(S_{15}\right) \\
=0.35\end{array}$ & - & $\begin{array}{l}\mu_{M m}\left(S_{17}\right) \\
=0.42\end{array}$ \\
\hline$E_{2}$ & $\begin{array}{l}\mu_{M M}\left(S_{21}\right) \\
=0.24\end{array}$ & $\begin{array}{l}\mu_{m M}\left(S_{22}\right) \\
=0.14\end{array}$ & $\begin{array}{l}\mu_{M M}\left(S_{23}\right) \\
=0.27\end{array}$ & $\begin{array}{l}\mu_{m M}\left(S_{24}\right) \\
=0.45\end{array}$ & $\begin{array}{l}\mu_{M M}\left(S_{25}\right) \\
=0.9\end{array}$ & $\begin{array}{l}\mu_{m M}\left(S_{26}\right) \\
=0.12 \\
\mu_{M M}\left(S_{26}\right) \\
=0.12\end{array}$ & $\begin{array}{l}\mu_{M M}\left(S_{27}\right) \\
=0.9\end{array}$ \\
\hline$E_{3}$ & $\begin{array}{l}\mu_{M M}\left(S_{31}\right) \\
=0.6\end{array}$ & $\begin{array}{l}\mu_{m M}\left(S_{32}\right) \\
=0.07\end{array}$ & $\begin{array}{l}\mu_{M M}\left(S_{33}\right) \\
=0.8\end{array}$ & $\begin{array}{l}\mu_{m M}\left(S_{34}\right) \\
=0.27\end{array}$ & $\begin{array}{l}\mu_{M M}\left(S_{35}\right) \\
=0.63\end{array}$ & $\begin{array}{l}\mu_{m M}\left(S_{36}\right) \\
=0.2 \\
\mu_{M M}\left(S_{36}\right) \\
=0.2\end{array}$ & - \\
\hline$E_{4}$ & $\begin{array}{l}\mu_{M M}\left(S_{41}\right) \\
=0.54\end{array}$ & $\begin{array}{l}\mu_{m M}\left(S_{42}\right) \\
=0.35\end{array}$ & $\begin{array}{l}\mu_{M M}\left(S_{43}\right) \\
=0.9\end{array}$ & $\begin{array}{l}\mu_{m M}\left(S_{44}\right) \\
=0.09\end{array}$ & - & $\begin{array}{l}\mu_{m M}\left(S_{46}\right) \\
=0.5 \\
\mu_{M M}\left(S_{46}\right) \\
=0.5\end{array}$ & $\begin{array}{l}\mu_{M M}\left(S_{47}\right) \\
=0.27\end{array}$ \\
\hline$E_{5}$ & $\begin{array}{l}\mu_{M m}\left(S_{51}\right) \\
=0.48\end{array}$ & $\begin{array}{l}\mu_{m m}\left(S_{52}\right) \\
=0.7\end{array}$ & - & $\begin{array}{l}\mu_{m m}\left(S_{54}\right) \\
=0.64\end{array}$ & $\begin{array}{l}\mu_{M m}\left(S_{55}\right) \\
=0.72\end{array}$ & $\begin{array}{l}\mu_{m m}\left(S_{56}\right) \\
=0.1 \\
\mu_{M m}\left(S_{56}\right) \\
=0.1\end{array}$ & $\begin{array}{l}\mu_{M m}\left(S_{57}\right) \\
=0.24\end{array}$ \\
\hline$E_{6}$ & - & $\begin{array}{l}\mu_{m m}\left(S_{62}\right) \\
=0.42\end{array}$ & $\begin{array}{l}\mu_{M m}\left(S_{63}\right) \\
=1\end{array}$ & $\begin{array}{l}\mu_{m m}\left(S_{64}\right) \\
=0.18\end{array}$ & $\begin{array}{l}\mu_{M m}\left(S_{65}\right) \\
=0.72\end{array}$ & $\begin{array}{l}\mu_{m m}\left(S_{66}\right) \\
=0.25 \\
\mu_{M m}\left(S_{66}\right) \\
=0.25\end{array}$ & $\begin{array}{l}\mu_{M m}\left(S_{67}\right) \\
=0.54\end{array}$ \\
\hline
\end{tabular}

The main weakness of Magneti Marelli's branch in Serbia is the high cost structure. To overcome that weakness while faced with external threats - such as decline in demand and growing competition from Johnson Controls - two Mini-mini strategies $\left(S_{12}\right.$ and $\left.S_{52}\right)$ are proposed.

Generally, the results showed that the fuzzy TOWS model can be useful in the strategy development process, and that it can lead to the formulation of appropriate strategies for the Magneti Marelli branch in Serbia.

Further research could analyse the differences in developing strategic alternatives for Magneti Marelli branches in different countries in Eastern Europe. The results could be discussed by taking into consideration the economic changes and social and cultural differences between those countries.

\section{CONCLUSIONS}

In this paper we develop an alternate approach to the quantification of the TOWS conceptual framework. The proposed approach is based on fuzzy logic, a methodology well 
suited to the process of management planning and strategy formulation when managers have to make decisions with incomplete information and under uncertain circumstances [17].

The fuzzy model of the TOWS strategic concept provides a convenient answer to the problem of ambiguity and uncertainty about internal strengths and weaknesses and external opportunities and threats. In that sense, the main advantage of the fuzzy approach over traditional quantitative approaches is that it uses fuzzy numbers to assess and describe vague information better [18].

Specifically, we addressed the issue of how to deploy the model effectively and efficiently to assess the major strengths, weaknesses, opportunities, and threats relating to the Magneti Marelli production facilities in Serbia.

Information obtained from the Magneti Marelli management team provided realistic insight into the organisation's current state of resources and overall capabilities, considering changes and dynamics in the environment. On that basis, the fuzzy model of the TOWS concept was used to develop and evaluate strategic alternatives.

Considering the fact that a systematic approach that incorporates fuzzy set theory could assist managers to reach a better understanding of overall competitiveness [19], the proposed fuzzy TOWS model also has the advantage of being relatively simple and adjustable by the user. Additionally, the case study has shown that it is easy to understand and implement because the application of this technique does not require advanced mathematical knowledge.

Generally, from a management perspective, the fuzzy TOWS matrix provides a comprehensive framework for generating sustainable strategies on a regular basis. In that sense, it could be seen as an adaptive and flexible tool that supports managers in making a more realistic quantitative assessment of alternative strategies and developing optimal solutions.

\section{REFERENCES}

[1] Weihrich, H. 1982. The TOWS matrix-A tool for situational analysis, Long Range Planning, 15(2), pp 54-66.

[2] Ravanavar, G.M. \& Charantimath, P.M. 2012. Strategic formulation using TOWS matrix - A case study, International Journal of Research and Development, 1(1), pp 87-90.

[3] David, F.R. 2006. Strategic management: Concepts and cases, 11th edition. Prentice Hall Publishing Company: Upper Saddle River, N.J.

[4] Weihrich, H. 1993. Daimler-Benz's move towards the next century with the TOWS matrix, European Business Review, 93(1), pp 4-11.

[5] Ghazinoory, S., Esmail Zadeh, A. \& Memariani, A. 2007. Fuzzy SWOT analysis, Journal of Intelligent \& Fuzzy Systems, 18, pp 99-108.

[6] Zimmermann, H.J. 2001. Fuzzy set theory and its applications, $4^{\text {th }}$ edition. Kluwer Academic Publishers Group, Boston.

[7] Mansur, Y.M. 1995. Fuzzy sets and economics: Applications of fuzzy mathematics to noncooperative oligopoly. Edward Elgar Publishing Limited, Aldershot.

[8] Jia, G.Z. \& Bai, M. 2011. An approach for manufacturing strategy development based on fuzzyQFD, Computers \& Industrial Engineering, 60(3), pp 445-454.

[9] Wang, Y.M. \& Elhag, T.M.S. 2006. On the normalisation of interval and fuzzy weights. Fuzzy Sets and Systems, 157, pp 2456-2471.

[10] Chinho, L. \& Hsieh, P.J. 2003. A fuzzy decision support system for strategic portfolio management, Decision Support Systems, 38, pp 383-398.

[11] Parreiras, R.O., Ekel, P.Y. \& Morais, D.C. 2012. Fuzzy set based consensus schemes for multicriteria group decision making applied to strategic planning, Group Decision and Negotiation, 21(2), pp 153-183. 
[12] Li, S. \& Li, J.Z. 2009. Hybridising human judgment, AHP, simulation and a fuzzy expert system for strategy formulation under uncertainty, Expert Systems with Applications, 36(3), pp 55575564.

[13] Orriols-Puig, A., Martinez-Lopez, F.J., Casillas, J. \& Lee, N. 2013. A soft-computing-based method for the automatic discovery of fuzzy rules in databases: Uses for academic research and management support in marketing, Journal of Business Research, 66(9), pp 1332-1337.

[14] Barkhuizen, W.F., Pretorius, J.H.C. \& Pretorius L. 2012. An integrated systems approach to risk management within a technology-driven industry, using the design structure matrix and fuzzy logic, South African Journal of Industrial Engineering, 23(2), pp 202-214.

[15] Jetter, A.J. \& Kok, K. 2014. Fuzzy cognitive maps for futures studies - A methodological assessment of concepts and methods, Futures, 61, pp 45-57.

[16] Lu, J., Zhang, G. \& Ruan, D. 2008. Intelligent multi-criteria fuzzy group decision-making for situation assessments, Soft Computing, 12(3), pp 289-299.

[17] Pesic, A. \& Pesic, D. 2011. Diagram of the information systems factors - Fuzzy approach, I International Symposium Engineering Management And Competitiveness 2011 (EMC2011), The Book of Proceedings, Zrenjanin, pp 423-427.

[18] Pesic, A., Pesic, D. \& Tepavcevic A. 2012. A new strategic tool for internal audit of the company based on fuzzy logic, ComSIS Journal, 9(2), pp 653-666.

[19] Lin, C., Tan, B. \& Hsieh, P.J. 2005. Application of the fuzzy weighted average in strategic portfolio management, Decision Science, 36(3), pp 489-511. 